\title{
Fall Saw-Whet Owl Concentrations in Ontario
}

\author{
by Robert B. Taylor, Scarborough, Ontario
}

There are many phenomenal occurrences in nature which draw human interest and invite investigation. One such case is the migratory flight of the tiny Saw-whet Owl. Each fall, from early October until mid-November, hundrcls of these big-eyed balls of feather journey southwards, on rapidly beating wings, from their breeding areas in the mixed and coniferous forests of the north.

Along the north shores of lakes Ontario and Erie there occurs a "damming up" of these birds resulting in large concentrations of them at various points along the shores; notably at Toronto and Point Pelee. The Saw-whets seem to prefer large areas of scrub willows and red osier dogwoods as long as they have their leaves. When the leaves fall, the owls take more readily to conifers-particularly cedars and hemlocks. They can be found perching at almost any height, from ground level to thirty or forty feet up, but are most commonly found between four and twelve feet.

There are numerous theories as to why the Saw-whets concentrate on the north shores. Many people believe that the owls migrate south to the two lakes then follow the shoreline west and south, crossing over at the west end of the Detroit River. The writer holds a theory, stimulated by reports of Saw-whets bcirding ships in the Great Lakes, that the owls stop to rest up for a day before attempting to fly the unknown distance across the lake. Then after a day's rest, it is thought that they proceed to fly directly across rather than follow the shoreline. Some observations that may or may not prove to support this latter theory are as follows: recoveries of banded owls on days immediately subsequent to the date of banding, during the fall migration, are extremely rare; there are several records of Saw-whets boarding ships in the Great Lakes; observations seem to indicate larger concentrations of owls after rainy or windy nights when direct flight across the lakes would be difficult even if the birds were well rested; there are few records of this species from the Hamilton area at the west end of Lake Ontario where they conceivably would pass right through until arriving at the Lake Erie shore south of Hamilton; and there are a significant number of records from Pelee Island in Lake Erie to indicate that they do cross southwards that far, across a large expanse of water, from Point Pelee.

For approximately twenty years now, bird banders in the Toronto area have taken advantage of the abundance of Saw-whets and the ease of their capture and have succeeded in banding a number estimated at well over two thousand. In an area of approximately twenty acres on Toronto Island, the writer captured 36 Sawwhets in a six hour period on October 21,1961 , and 40 more in the same area the following day. Four additional birds which were not captured were seen during those two days. Plumage notes, weights, measurements, and fat deposition notes were made for all these birds and they were banded and released on the same day shortly after they were captured. The records were placed with over 200 sets of similar data previously accumulated. It is hoped that analysis of this data will yield considerable information on aging, sexing, and migration of Saw-whets.

Saw-whets are usually quite tolerant of human advances. When approached, they straighten up, draw their feathers in tightly to the body, making themselves appear as long and thin as possible, and remain quite motionless. This attempt to avoid detection is termed "freezing." Because of this habit, it is often possible for banders to grab them from the branch with the bare hand. Often mist nets are employed to catch them, especially when one is encountered that will not allow the person to approach closely. Efforts to net them at night with strategically placed mist nets have proven successful, and it is hoped that the future will see more sleepless nights spent on this activity. 


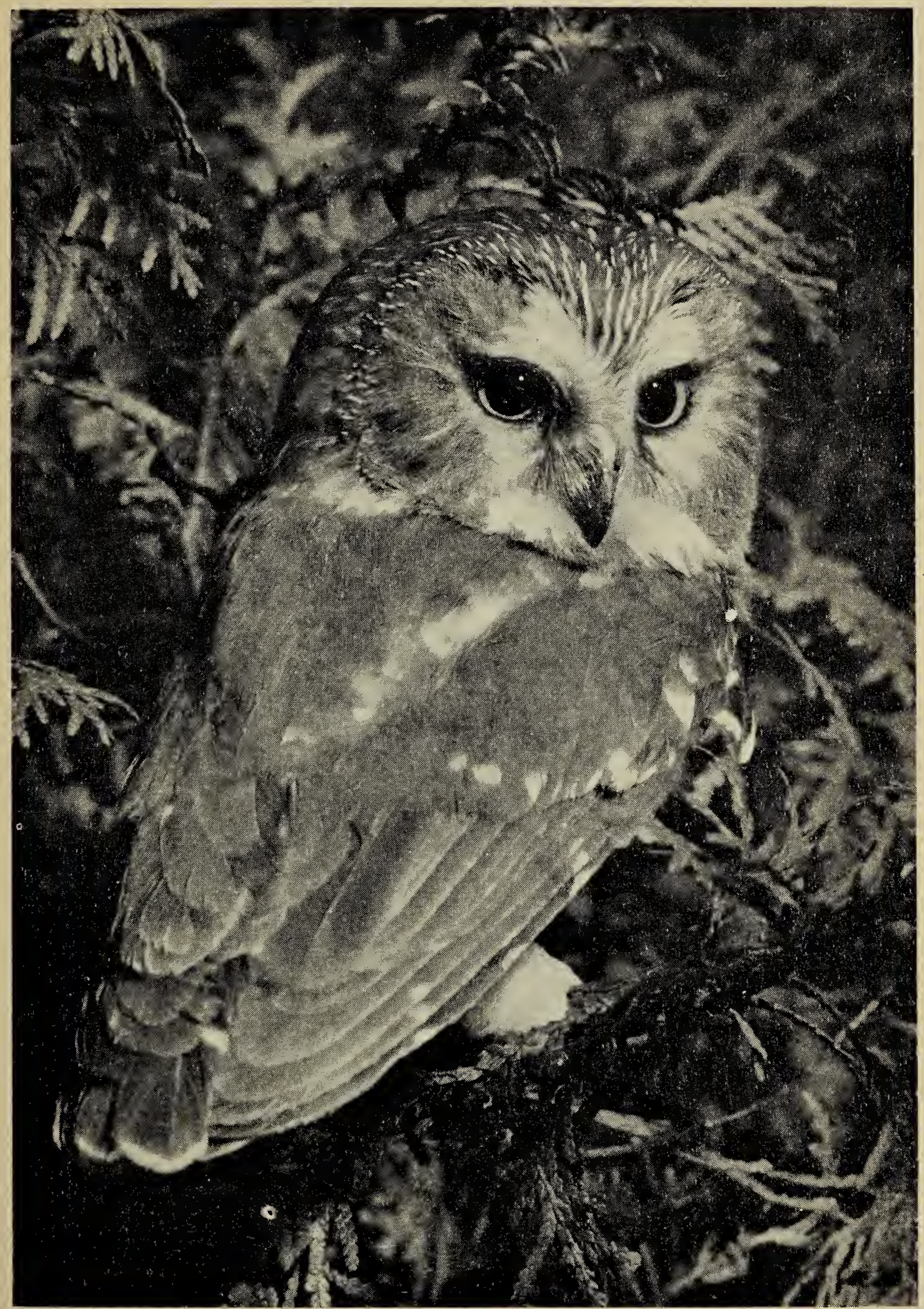

